\title{
Analysis of Two Clonal Lines (Embryogenic and Non-Embryogenic) of Agave fourcroydes Using AFLP and MSAP
}

\author{
Kelly M. Monja-Mio', Adriana Quiroz-Moreno ${ }^{1}$, Gastón Herrera-Herrera', \\ Jorge Luis Montero-Muñoz ${ }^{2}$, Felipe Sánchez-Teyer ${ }^{1}$, Manuel L. Robert ${ }^{1}$ \\ ${ }^{1}$ Unidad de Biotecnología, Centro de Investigación Científica de Yucatán, Mérida, México \\ ${ }^{2}$ Centro de Investigación y Estudios Avanzados I.P.N. (Cinvestav), Mérida, México \\ Email:robert@cicy.mx
}

How to cite this paper: Monja-Mio, K.M., Quiroz-Moreno, A., Herrera-Herrera, G., Montero-Muñoz, J.L., Sánchez-Teyer, F. and Robert, M.L. (2018) Analysis of Two Clonal Lines (Embryogenic and Non-Embryogenic) of Agave fourcroydes Using AFLP and MSAP. American Journal of Plant Sciences, 9, 745-762.

https://doi.org/10.4236/ajps.2018.94059

Received: December 9, 2017

Accepted: March 16, 2018

Published: March 19, 2018

Copyright $\odot 2018$ by authors and Scientific Research Publishing Inc. This work is licensed under the Creative Commons Attribution International License (CC BY 4.0).

http://creativecommons.org/licenses/by/4.0/

\section{(c) (i) Open Access}

\begin{abstract}
Somatic embryogenesis is a very efficient way to propagate economically important plants; however, not all genotypes within a species can be propagated using this method, as a combined effect of both genetic and epigenetic mechanisms may be involved in the response. The aim of the present study was to perform a comparative analysis of the genetic differences through amplified fragment length polymorphism (AFLP) and the epigenetic differences through methylation-sensitive amplified polymorphism (MSAP) of two Agave fourcroydes clonal lines, one highly embryogenic (K33) and the other non-embryogenic (K7). Genetic and epigenetic variabilities existed within each clonal line; however, the polymorphic profiles from the two marker systems allowed us to clearly distinguish the two clonal lines before somatic embryogenesis induction. During the induction, the changes detected were mainly 1) unmethylated fragments in the initial explants that were methylated during induction (methylation events) and 2) fragments with different methylation states in the initial explant that were unmethylated in some stages of the process (demethylation events). K33 showed greater dynamism in relation to methylation/demethylation events, while $\mathrm{K} 7$ presented the methylation events in a more constant range and at higher levels during all process.
\end{abstract}

\section{Keywords}

Agave, Clonal Line, Somatic Embryogenesis, DNA Methylation

\section{Introduction}

Somatic embryogenesis (SE) is a complex developmental process through which somatic plant cells, under certain in vitro culture conditions, present metabolic, 
genetic, and epigenetic changes and cellular reprogramming that result in embryo production [1] [2]. This process involves culturing an explant (of appropriate tissue type and genotype) in a medium with a suitable combination of growth regulators [3].

The genotypic influence is a problem for the establishment of culture protocols because only some genotypes within a species are responsive to induction of SE. In addition to this genetically determined capability, variation may also be due to epigenetic changes, particularly in the pattern of chromatin condensation [3].

DNA methylation is an epigenetic mechanism that is crucial for diverse biological processes [4]. The relationship between DNA methylation and SE has been reported as the cause of the tissue specificity of explants [5] [6], the embryogenic capacity of cells in culture [7], changes that take place during cellular differentiation [8], changes in developmental state [9] [10] [11], cell culture aging [12] [13], the expression of embryogenesis-related genes [2] [14] [15] and the fidelity (trueness to type) of plants obtained by SE [13] [16] [17]. However, there are no reports on the effects of methylation and genotypes (embryogenic and non-embryogenic).

Amplified fragment length polymorphism (AFLP) and methylation-sensitive amplified polymorphism (MSAP) have similar experimental procedures; however, AFLP detects restriction site variations, and MSAP detects variations in cytosine methylation at CCGG sites [18]. AFLP is an efficient molecular marker that has been widely used to estimate genetic variability in plants [18] [19] [20] [21], and MSAP has been used as a genome-wide screening method to assess global DNA methylation [22] [23]. In plants, MSAP has been mostly used to identify differences in DNA methylation patterns [24] [25] [26] [27] [28] but has also been used to identify epigenetic variation in populations [29] [30] [31].

Agaves are plants used in the production of a wide variety of products, including liquors, fibers, cellulose and inulin [32]. Genotype-dependent responses have been observed in the SE of $A$. fourcroydes, where induction from stems of plantlets cultured in vitro has shown that the embryogenic capacity varies [33].

The current study aimed to compare two molecular marker systems, AFLP and MSAP, using two clonal lines, one with high embryogenic capacity (K33) and a non-embryogenic clonal line (K7), for SE induction. Furthermore, an analysis of methylation events during the SE induction of both clonal lines was performed.

\section{Materials and Methods}

\subsection{A. fourcroydes Clonal Lines and Induction of SE}

Shoots from $A$. fourcroydes clonal lines were used as the source of explant, obtained using the protocol of Robert et al. (2004). A clonal line includes all shoots derived from the same mother plant. The parental plants were young $(30-50 \mathrm{~cm}$ 
high) offshoots from selected elite plantation individuals in Telchac-Yucatán.

For this study, we chose a highly embryogenic clonal line (K33) that produces 100 embryos/explant and another non-embryogenic one (K7) that produces no embryos. Both clonal lines were grown in the same MSB maintenance medium [salts from Murashige and Skoog (MS) medium [35] with reduced nitrogen (10 $\mathrm{mM} \mathrm{KNO}_{3}$ and $5 \mathrm{mM} \mathrm{NH}_{4} \mathrm{NO}_{3}$ ) supplemented with $0.1 \mu \mathrm{M} \mathrm{2,4-D}$ and $44.4 \mu \mathrm{M}$ BA] before undergoing embryogenic induction.

For SE induction, the stems of shoots from both $A$. fourcroydes clonal lines were segmented into thin layers of approximately $0.5-\mathrm{mm}$ thickness, placed on MS medium supplemented with $2.26 \mu \mathrm{M}$ dicamba, 3\% $(w / v)$ sucrose, vitamin L2 [36] solidified with $0.3 \%(w / v)$ agar (Sigma-Aldrich G1910) and 0.3\% $(w / v)$ Phytagel $^{\mathrm{Tm}}$ (Sigma-Aldrich P8169) and cultured in the dark [33].

\subsection{DNA Extraction}

The method reported by Echevarría-Machado et al. (2005) [37] was used for genomic DNA extraction. The concentration and purity of DNA were determined by spectrophotometry (Thermo Scientific NanoDrop ${ }^{\mathrm{Tm}} 1000$ ), and its integrity was verified by electrophoresis on a $1 \%$ agarose gel.

\subsection{AFLP}

In addition to 5 individual samples, a pool (bulk) of each clonal line was formed, for which equimolar concentrations of DNA extracted from 20 shoots (one 100-ng DNA mixture per shoot) were taken. The bulks were realized to reduce the variability between individuals.

AFLP was performed as described by Vos et al. (1995) with slight modifications. Approximately 300 ng of genomic DNA was digested with $2 \mathrm{U}$ MseI and 2 $\mathrm{U}$ EcoRI restriction enzymes in a $20-\mu \mathrm{L}$ reaction. The ligation reaction was performed with $20 \mu \mathrm{L}$ of previously digested DNA, $1 \times$ ligase buffer, 5 pmol EcoRI adapters, 50 pmol MseI adapters, and $1 \mathrm{U}$ T4 DNA ligase in a $30-\mu \mathrm{L}$ reaction. The pre-amplification reaction was performed with $5 \mu \mathrm{L}$ of the $1: 5(\mathrm{v}: \mathrm{v})$ dilution of the ligation product, $10 \times$ PCR buffer, $1.5 \mathrm{mM} \mathrm{MgCl}_{2}, 0.2 \mathrm{mM} \mathrm{dNTPs}, 1 \mathrm{pmol}$ MseI primer, 1 pmol EcoRI primer, and $0.5 \mathrm{U}$ Taq DNA polymerase in a $20-\mu \mathrm{L}$ reaction. Selective amplification was performed in a $10-\mu \mathrm{L}$ reaction with $5 \mu \mathrm{L}$ of a 1:10 (v:v) dilution of the pre-amplification product, 1X PCR buffer, $1.5 \mathrm{mM}$ $\mathrm{MgCl}_{2}, 0.2 \mathrm{mM}$ dNTPs, $10.67 \mathrm{mM}$ MseI selective primer without label containing three user-selected nucleotides, $2.5 \mathrm{mM}$ EcoRI selective primer (3) labeled with Well RED dye (D2, D3, D4) and containing three selective nucleotides (Table 1), and $0.5 \mathrm{U}$ Taq DNA polymerase. PCR conditions were $5 \mathrm{~min}$ at $94^{\circ} \mathrm{C}$; 16 cycles of "touch-down" of $45 \mathrm{~s}$ at $94^{\circ} \mathrm{C}, 45 \mathrm{~s}$ at $60^{\circ} \mathrm{C}\left(0.5^{\circ} \mathrm{C}\right.$ decrease per cycle $)$ and $30 \mathrm{~s}$ at $72^{\circ} \mathrm{C} ; 16$ continuous cycles of $45 \mathrm{~s}$ at $94^{\circ} \mathrm{C}, 45 \mathrm{~s}$ at $52^{\circ} \mathrm{C}$ and $30 \mathrm{~s}$ at $72^{\circ} \mathrm{C}$; and $7 \mathrm{~min}$ at $72^{\circ} \mathrm{C}$.

Subsequently, $25 \mu \mathrm{L}$ of sample loading solution (SLS, GenomeLab ${ }^{\mathrm{TM}} \mathrm{N}^{\circ}$ 608082) was taken, and to this solution was added $0.25 \mu \mathrm{L}$ of STD 400 (DNA 
Table 1. List of AFLP/MSAP primers and adapters used. DNA sequences are given in the 5 ' to 3 ' orientation.

\begin{tabular}{|c|c|}
\hline Adapters/primers & Sequence $\left(5^{\prime}-3^{\prime}\right)$ \\
\hline \multicolumn{2}{|l|}{ Adapters } \\
\hline HpaII/MspI-adapter I & 5'-CGACTCAGGACTCAT-3' \\
\hline HpaII/MspI-adapter II & 5'-GACGATGAGTCCTGAGT-3' \\
\hline EcoRI-adapter I & 5'-CTCGTAGACTGCGTACC-3' \\
\hline EcoRI-adapter II & 5'-AATTGGTACGCAGTCTAC-3' \\
\hline Mse1-adapter I & 5'-GACGATGAGTCCTGAG-3' \\
\hline Mse1-adapter II & 5'-TACTCAGGACTCAT-3' \\
\hline \multicolumn{2}{|l|}{ Pre-amplification primers } \\
\hline HpaII/MspI-pre & 5'-GATGAGTCCTGAGTCGG-3’' \\
\hline Eco-pre & 5'-GACTGCGTACCAATTCA-3' \\
\hline Mes-pre & 5'-GATGAGTCCTGAGTAAC-3' \\
\hline \multicolumn{2}{|c|}{ Selective amplification primers } \\
\hline \multicolumn{2}{|c|}{$H p a I I / M s p \mathrm{I}$ primers } \\
\hline HM-CTA & 5'-GATGAGTCCTGAGTCGGCTA-3' \\
\hline HM-CAG & 5'-GATGAGTCCTGAGTCGGCAG-3' \\
\hline HM-CTT & 5'-GATGAGTCCTGAGTCGGCTT-3' \\
\hline \multicolumn{2}{|l|}{ EcoRI-primers } \\
\hline EcoR-ACG & 5'-GACTGCGTACCAATTCACG-3' \\
\hline$E c o R$-AAC & 5'-GACTGCGTACCAATTCAAC-3' \\
\hline EcoR-ACA & 5'-GACTGCGTACCAATTCACA-3' \\
\hline$E c o R$-ACT & 5'-GACTGCGTACCAATTCACT-3' \\
\hline$E c o R-A A G$ & 5'-GACTGCGTACCAATTCAAG-3' \\
\hline$E c o R$-ACC & 5'-GACTGCGTACCAATTCACC-3' \\
\hline \multicolumn{2}{|l|}{ MseI-primers } \\
\hline$M s e I$-CTA & 5'-GATGAGTCCTGAGTAACTA-3' \\
\hline MseI-CTT & 5'-GATGAGTCCTGAGTAACTT-3' \\
\hline MseI-CAG & 5'-GATGAGTCCTGAGTAACAG-3' \\
\hline
\end{tabular}

Size Standard Kit-400 GenomeLab $\left.{ }^{\mathrm{TM}} \mathrm{N}^{\circ} 608098\right)$ and $2 \mu \mathrm{L}$ of diluted sample (2 $\mu \mathrm{L}$ of selective amplification product $+4 \mu \mathrm{L}$ of formamide SLS) plus one drop of oil to prepare the plate that was run in the sequencer (Beckman CQ800).

\subsection{MSAP}

Samples were collected before the induction (day 0, prior to induction) and during induction (days 1, 3, 7, 15, 30,45). Three replicates were made each day, each of which consisted of segmented stems from different individuals on the corresponding sampling day.

MSAP is a variant of AFLP that allows us to detect methylation patterns of genomic DNA using digestion enzymes that are sensitive to methylation. Sam- 
ples were analyzed using the method reported by [39]. In this protocol, the frequent cutter MseI was replaced with two isoschizomers: HpaII and MspI. Conditions for digestion, ligation, pre-amplification, selective amplification and sample preparation for sequencing were the same as described in the AFLP protocol. Selective amplification included a total of five combinations (Table 1), from which the one with the greatest amount of polymorphism was selected. To reduce the possibility of artifacts, three replicates from different extractions were used for each combination.

\subsection{Analysis of Data Obtained by AFLP and MSAP}

Gene Marker ${ }^{\mathrm{TM}}$ software was used to obtain polymorphic profiles from both AFLP and MSAP. Automatic fragment detection criteria included fluorescence intensity greater than 50 units and a range of fragment sizes of 50 to $350 \mathrm{bp}$. Data were sorted into binary 0 - 1 matrices, where 0 means the absence and 1 the presence of the fragment.

In AFLP, fragment analysis consisted of a comparative study of the results, in which we determined the total number of fragments and the numbers of monomorphic and polymorphic fragments. The genetic similarity index was determined according Nei and Li [40].

In MSAP, the isoschizomers HpaII and MspI recognize the same tetranucleotide sequence (5'-CCGG-3') but differ in their sensitivity to the methylation status of the recognition site. This difference allows classification into four types [41]: Type I: when the resulting fragment came from digestion with both enzymes, it was unmethylated; type II: when the resulting fragment only came from digestion by EcoRI + MspI, it indicated a complete methylation profile or hemi-methylation of the internal cytosine $\left(\mathrm{C}^{\mathrm{Me}} \mathrm{CGG} / \mathrm{C}^{\mathrm{HMe}} \mathrm{CGG}\right)$; type III: when the fragment only came from digestion of EcoRI + HpaII, it indicated a hemi-methylation profile of the external cytosine $\left({ }^{\mathrm{HMe}} \mathrm{CCGG}\right)$; and type IV: when there was no cut by any of the enzymes, it indicated that no fragments were generated; this result may have been due to complete methylation of the external cytosine $\left({ }^{\mathrm{Me}} \mathrm{CCGG}\right)$, complete methylation of both cytosines $\left({ }^{\mathrm{Me}} \mathrm{C}^{\mathrm{Me}} \mathrm{CGG}\right)$, hemi-methylation of both cytosines $\left({ }^{\mathrm{HMe}} \mathrm{C}^{\mathrm{HMe}} \mathrm{CGG}\right.$ ) or an actual absence of the fragment due to a polymorphism at the restriction site.

A site was considered a "polymorphic fragment" $(\mathrm{PF})$ if there was at least one line in which the site was methylated and at least one line in which the site was not methylated. The numbers of specific fragments were also calculated across the clonal lines. Specific fragments are clonal line-specific and found only in a single clonal line.

\subsection{Statistical Analysis}

MSAP profiles were analyzed using the $\mathrm{R}$ environment ( $\mathrm{R}$ Development Core Team, 2012) running package msap (v.1.1.6) [23]. This package uses four main steps: data input, fragment classification, data transformation and data analysis; 
the Error Rate-based Threshold (ERT) is set as $5 \%$ by default. Briefly, the package uses a binary matrix indicating the presence (1) or absence (0) of EcoRI-MspI and EcoRI-HpaII fragments in the samples of each group. Then, the fragments are classified based on the four possible types described above [Msp 1/HPA1 (Type I), Msp 1/HPA0 (Type II), Msp 0/HPA1 (Type III) and Msp 0/HPA0 (Type IV)]. Posteriorly, it determines if each fragment is susceptible to methylation (MSL: Methylation Susceptible Loci) or if there is no evidence of methylation (NML: Non-Methylated Loci), following the procedure in Herrera \& Bazaga [30]. The package uses a Euclidean distance matrix. The epigenetic variation is estimated using the Shannon diversity index. Within the MSL, the package provides a report of the related methylation levels for every group. The epigenetic differentiation is assessed by principal coordinate analysis (PCoA) and is tested using analyses of molecular variance (AMOVA; [42]) with 10,000 permutations. For the AFLP technique, the package skips all data transformation and classification of MSL/NML and goes directly to diversity/differentiation analysis.

\section{Results}

\subsection{Genetic and Epigenetic Differences within and between Clonal Lines}

To evaluate and characterize the genetic and epigenetic differences between two clonal lines (embryogenic and non-embryogenic) of $A$. fourcroydes, the AFLP and MSAP techniques were used. A polymorphism survey was performed within one clonal line (to assess the occurrence of variability) and among the clonal lines (to reveal differential epigenetic and genetic profiles).

A total of five AFLP primer combinations (Table 1) were used to generate AFLP profiles. The primer combinations that produced the greatest polymorphism were EcoRI-AAC/MseI-CTA, EcoRI-ACG/MseI-CAG and EcoRI-ACA/MseI-CTT. AFLP analysis revealed 258 total fragments distributed in the 12 samples of the two clonal lines. The numbers of polymorphic fragments were $142(55.04 \%)$ for K33 and 167 (64.73\%) for K7. The numbers of monomorphic fragments were 116 (44.96\%) for K33 and 91 (35.27\%) for K7. The numbers of specific fragments were 41 for K33 and 18 for K7 (Table 2). According to the Nei and Li coefficient, the similarity index varied from 0.72 to 0.91 , with an average of 0.81 for the three primer combinations.

A total of five MSAP primer combinations (Table 1) were deployed to generate MSAP profiles. The primer combinations that produced the greatest polymorphism were EcoRI-ACA/MH-CTA, EcoRI-ACA/MH-CAG and EcoRI-ACA/MH-CTT. MSAP analysis revealed 199 total fragments distributed in the 8 samples of the two clonal lines. The numbers of polymorphic fragments were $52(26.13 \%)$ for K33 and 47 (23.62\%) for K7. The numbers of monomorphic fragments were 147 (52\%) for K33 and 152 (76.38\%) for K7. The numbers of specific fragments were 29 for K33 and 34 for K7 (Table 2). 
Table 2. Polymorphism based on AFLP and MSAP marker between two clonal lines, K33 and K7.

\begin{tabular}{ccccccccc}
\hline Marker & Clonal line & Samples & TF & MF & PF & $\%$ MF & $\%$ PF & CEF \\
\hline \multirow{2}{*}{ AFLP } & K33 & 6 & \multirow{2}{*}{ K38 } & 116 & 142 & 44.96 & 55.04 & 41 \\
& K7 & 6 & & 91 & 167 & 35.27 & 64.73 & 18 \\
\multirow{2}{*}{ MSAP } & K33 & 4 & & 147 & 52 & 73.87 & 26.13 & 29 \\
& K7 & 4 & 199 & 152 & 47 & 76.38 & 23.62 & 34 \\
\hline
\end{tabular}

TF: Total number of fragments; MF: Number of monomorphic fragments; PF: Number of polymorphic fragments; PP: Percentage polymorphism; CEF: Number of clone-especific fragments.

AMOVA revealed that the variances within clonal lines were greater than the variances between clonal lines for both AFLP and MSAP (Table 3). However, differences relating to genetic patterns (AFLP) were statistically significant between clonal lines (AMOVA; differentiation among clonal lines: Phi_ST = $0.2353, P=0.0015)$. Differences relating to the genome-wide methylation patterns (MSAP) were also statistically significant between both lines (AMOVA; differentiation among clonal lines: Phi_ST $=0.2548, \mathrm{P}=0.0267$ ).

PCoA of the AFLP and MSAP profiles was performed to visualize the clustering patterns of the clonal lines (Figure 1). PCoA revealed a clear separation between the two clonal lines for both AFLP $(\mathrm{C} 1,25 \%$ and $\mathrm{C} 2,12.4 \%$ of variance explained) and MSAP (C1, 25\% and C2, 12.4\% of variance explained).

\subsection{DNA Methylation Patterns between Clonal Lines before SE Induction}

The msap package identified a total of 186 MSL (Methylation Susceptible Loci) and 13 NML (Non-Methylated Loci). The frequencies (expressed as percentages) of the different states of methylation at the target sequences in $\mathrm{K} 33$ and $\mathrm{K} 7$ are displayed in Table 4. The methylation levels in MSL were 78.64\% for K33 and 81.95\% for K7.

Furthermore, the total fragments were classified into 16 combinations, "A to E" (Table 5), per their banding patterns to analyze the pairwise comparison of fragments between $\mathrm{K} 33$ and $\mathrm{K} 7$. The banding patterns were classified into two types: same (A1 to A4) and different (B1 to E3). Pairwise comparisons revealed that 89 fragments were grouped as same patterns ( $48.24 \%$ of all methylated sites) and 73 fragments were grouped as different patterns $(51.76 \%$ of all methylated sites). Figure 2 illustrates some of the different patterns observed between the clonal lines.

\subsection{DNA Methylation Patterns during SE Induction}

During $S E$ induction (1, 3, 8, 15, 30 and 45 days) (Figure 3(a)), the banding patterns of clonal lines were also observed. Patterns were grouped according to events that occurred during the entire process in relation to the initial pattern (day 0 ). These profiles were classified into three types of events as methylation (ME), demethylation (DM) and no change (NC). The results showed a particular 
Table 3. Analysis of molecular variance results between clonal lines (K33 and K7) in reference to two techniques used.

\begin{tabular}{cccccccc}
\hline Marker & & $\mathrm{df}$ & SSD & MSD & Variance & Phi_ST & $P$-value \\
\hline \multirow{4}{*}{ AFLP } & Among clonal lines & 1 & 75.75 & 75.75 & 8.189 & 0.2353 & 0.0015 \\
& Within clonal lines & 10 & 266.2 & 26.62 & 26.62 & & \\
\multirow{2}{*}{ MSAP } & Total & 11 & 341.9 & 31.08 & & & \\
& Among clonal lines & 1 & 32.18 & 32.18 & 4.647 & 0.2548 & 0.0267 \\
& Within clonal lines & 6 & 81.56 & 13.59 & 13.59 & & \\
& Total & 7 & 113.7 & 16.25 & & & \\
\hline
\end{tabular}

df: degrees of freedom, SSD: Sum of Squares Differences, MSD: Mean Squares Deviation, $P$-values were derived from a random permutation test with 10,000 permutations.

Table 4. Report of methylation levels in each clonal line. Percentages are referred to the total number of polymorphic loci after the error rate filtering.

\begin{tabular}{|c|c|c|c|c|}
\hline \multicolumn{2}{|c|}{ Band pattern } & \multirow{2}{*}{ State } & \multirow{2}{*}{$\begin{array}{c}\text { Embryogenic } \\
\text { clonal line } \\
\text { K33 }\end{array}$} & \multirow{2}{*}{$\begin{array}{c}\text { Non-embryogenic } \\
\text { clonal line }\end{array}$} \\
\hline MspI & HpaII & & & \\
\hline 1 & 1 & Unmethylated (Type I) & $21.36 \%$ & $18.05 \%$ \\
\hline 1 & 0 & Internal cytosine methylation (Type II) & $17.55 \%$ & $22.02 \%$ \\
\hline 0 & 1 & Hemimethylated (Type III) & $16.39 \%$ & $17.88 \%$ \\
\hline 0 & 0 & Full methylation or absence of target (Type IV) & $44.70 \%$ & $42.05 \%$ \\
\hline
\end{tabular}

“0”: fragment absence; " 1 ": fragment presence.

dynamic, especially in the K33 clonal line (Figure 3(b)). In contrast, K7 had less significant changes throughout the process (Figure $3(\mathrm{c})$ ).

Methylation events (ME) at CCGG sites were greater in $\mathrm{K} 7$ and stayed constant throughout the process, in the range of $48.8 \%-56.2 \%$ (Figure 3(c)); in K33, they varied between $18.6 \%$ and $50 \%$ (Figure $3(\mathrm{~b})$ ). In K33, the highest peak in the ME was $50 \%$ at day 8 , which corresponds to the beginning of callus formation (Figure 3(a)). From day 15, which corresponds to the formation of embryogenic masses, the ME gradually decreased to $33.4 \%$. On day 30 , the formation of globular embryos is evident, and at day 45, other embryo stages are also found on the explant (Figure 3(a)). On both days, the ME were $31.3 \%$ for day 30 and $23.7 \%$ for day 45 .

Demethylation events (DE) at CCGG sites were higher in K33, ranging from $13 \%$ to $32.1 \%$ during the process; in $\mathrm{K} 7$, a narrower range of $8 \%$ to $13.6 \%$ was observed (Figure 3). In K33, the highest peak in the DE was $32.1 \%$, which corresponds to explant swelling (day 3). On day 8, which corresponds to callus formation, the DE were the lowest at only $13 \%$. Posteriorly, the DE gradually increased as the embryos developed (Figure 3(b)).

The events in which no changes were observed during the process (NC) ranged from $37 \%$ to $49.4 \%$ in K33 (Figure 3(b)); in K7, these events presented a more constant range of $35.2 \%-38.3 \%$ (Figure $3(\mathrm{c})$ ). 
Table 5. DNA methylation pattern at CCGG sites between two clonal lines (embryogenic and non-embryogenic) of Agave fourcroydes before induction of somatic embryogenesis.

\begin{tabular}{|c|c|c|c|c|c|c|c|}
\hline \multirow{3}{*}{ Methylathion } & \multirow{3}{*}{ Type } & \multicolumn{4}{|c|}{ Banding Pattern } & \multirow{3}{*}{$\begin{array}{l}\text { Number } \\
\text { of bands }\end{array}$} & \multirow{3}{*}{$\begin{array}{c}\text { Frequency } \\
\%\end{array}$} \\
\hline & & \multicolumn{2}{|c|}{$\begin{array}{l}\text { Embryogenic clonal } \\
\text { line (K33) }\end{array}$} & \multicolumn{2}{|c|}{$\begin{array}{l}\text { Non-embryogenic } \\
\text { clonal line (K7) }\end{array}$} & & \\
\hline & & $M s p \mathrm{I}$ & HpaII & MspI & HpaII & & \\
\hline \multirow{5}{*}{ 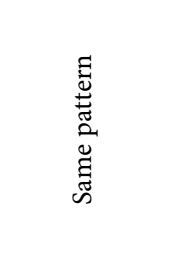 } & $\mathrm{A} 1$ & 1 & 1 & 1 & 1 & 20 & 10.05 \\
\hline & $\mathrm{A} 2$ & 1 & 0 & 1 & 0 & 10 & 5.03 \\
\hline & $\mathrm{A} 3$ & 0 & 1 & 0 & 1 & 8 & 4.02 \\
\hline & $\mathrm{A} 4$ & 0 & 0 & 0 & 0 & 58 & 29.15 \\
\hline & Total A & & & & & 96 & 48.24 \\
\hline \multirow{17}{*}{ 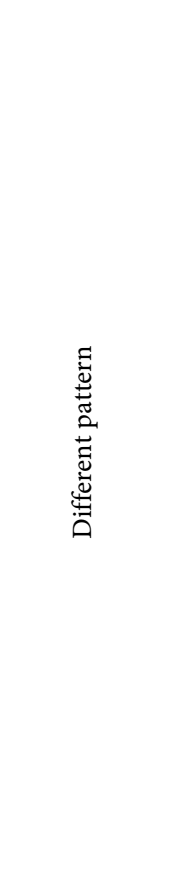 } & B1 & 1 & 0 & 1 & 1 & 8 & 4.02 \\
\hline & B2 & & & 0 & 0 & 19 & 9.55 \\
\hline & B3 & & & 0 & 1 & 1 & 0.50 \\
\hline & Total B & & & & & 28 & 14.07 \\
\hline & $\mathrm{C} 1$ & 0 & 1 & 1 & 1 & 5 & 2.51 \\
\hline & $\mathrm{C} 2$ & & & 0 & 0 & 13 & 6.53 \\
\hline & $\mathrm{C} 3$ & & & 1 & 0 & 5 & 2.51 \\
\hline & Total C & & & & & 23 & 11.55 \\
\hline & D1 & 1 & 1 & 0 & 0 & 10 & 5.03 \\
\hline & $\mathrm{D} 2$ & & & 1 & 0 & 4 & 2.01 \\
\hline & D3 & & & 0 & 1 & 9 & 4.52 \\
\hline & Total D & & & & & 23 & 11.56 \\
\hline & E1 & 0 & 0 & 1 & 1 & 6 & 3.02 \\
\hline & E2 & & & 1 & 0 & 19 & 9.55 \\
\hline & E3 & & & 0 & 1 & 4 & 2.01 \\
\hline & Total E & & & & & 29 & 14.58 \\
\hline & Total & & & & & 103 & 51.76 \\
\hline
\end{tabular}

"0": fragment absence; "1": fragment presence.

\section{Discussion}

\subsection{Genetic and Epigenetic Variation within and between the Clonal Lines}

In this work, we observed that epigenetic and genetic variability exists within and between the clonal lines of $A$. fourcroydes (Table 2 and Table 3 ).

It is possible that the variability observed within clonal lines may be due to tissue culture conditions. It has been reported that the stress occasioned by these conditions may produce gene mutations, epigenetic changes, and activation of transposable elements, leading to somaclonal variation [43] [44] [45] [46] [47].

In agaves, genetic fidelity in plants generated by in vitro culture has been studied in $A$. fourcroydes [48] and $A$. tequilana [49] [50]. Using AFLP as a molecular marker, González et al. (2003) detected 19.9\% polymorphisms when comparing mothers and their somatic embryogenesis-derived daughter plants of $A$. 
AFLP

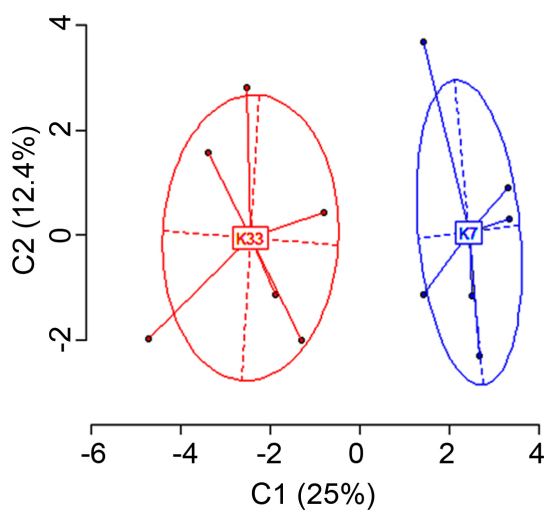

(a)
MSAP

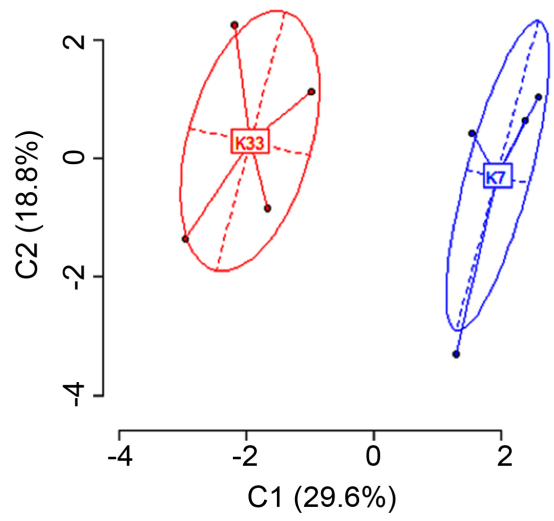

(b)

Figure 1. Principal coordinate analysis (PCoA) results for genetic (AFLP, panel (a)) and epigenetic (MSAP, panel (b)) differences between the two clonal lines, K33 and K7. The first two coordinates ( $\mathrm{C} 1$ and $\mathrm{C} 2)$ are shown, with the explained variance percentages in brackets. Different points represent individual samples. Labels indicate the centroids for the point cloud in each clonal line. Ellipses denote the average dispersion associated with each value. The long axis shows the direction of the maximum dispersion, while the short axis shows the direction of minimum dispersion.

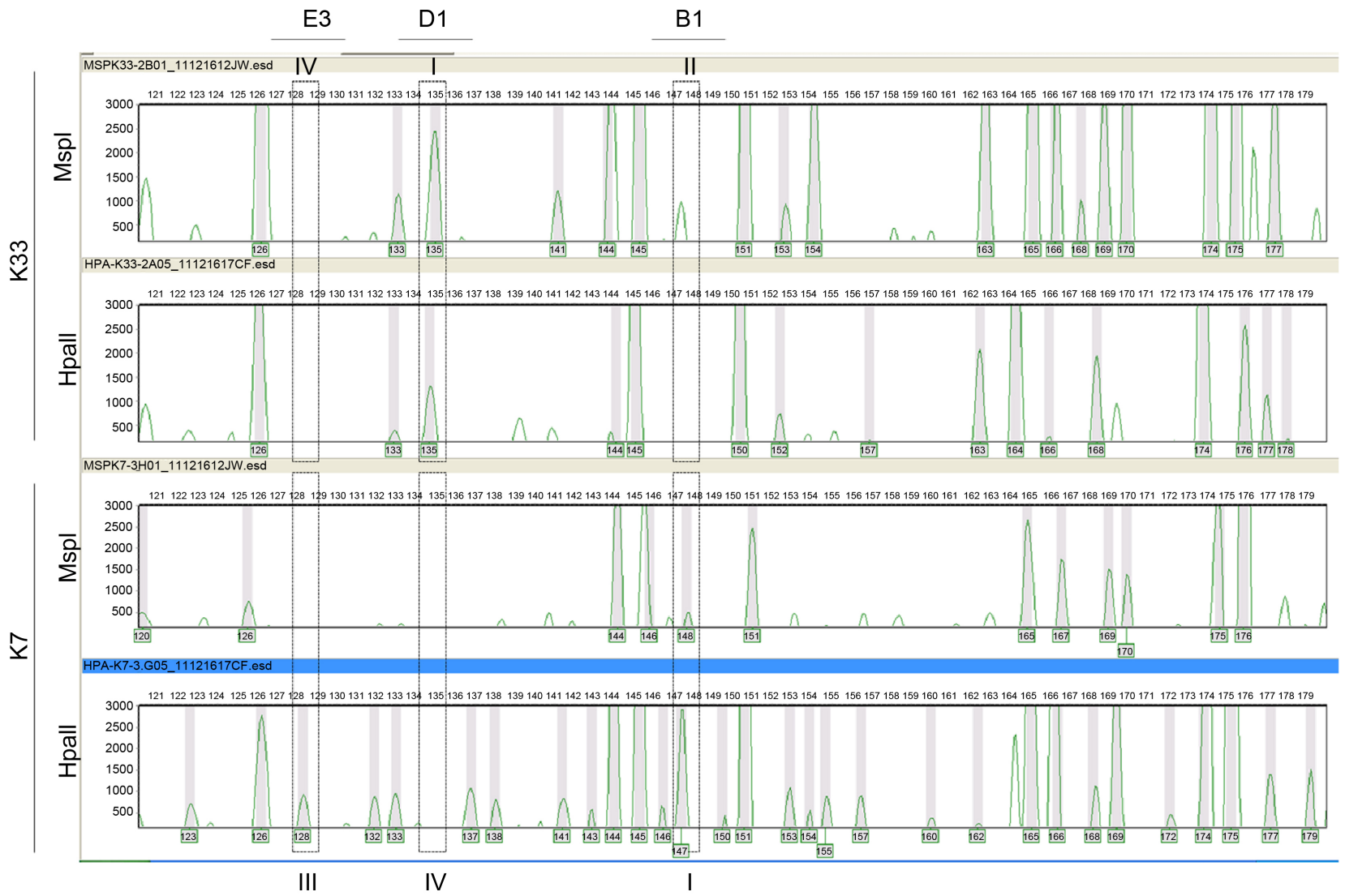

Figure 2. Representation of an electropherogram from MSAP showing unique methylation sites in each clonal line. I: unmethylated, II: ${ }^{\mathrm{HMe}} \mathrm{CG} /{ }^{\mathrm{Me}} \mathrm{CG}$, III: ${ }^{\mathrm{HMe}} \mathrm{CCG}$, IV: ${ }^{\mathrm{Me}} \mathrm{CCGG} /{ }^{\mathrm{HMe}} \mathrm{C}^{\mathrm{HMe}} \mathrm{CGG} /{ }^{\mathrm{Me}} \mathrm{C}^{\mathrm{Me}} \mathrm{CGG} /$ mutation. E3, D1 and B1: methylation patterns according to Table 5 . 

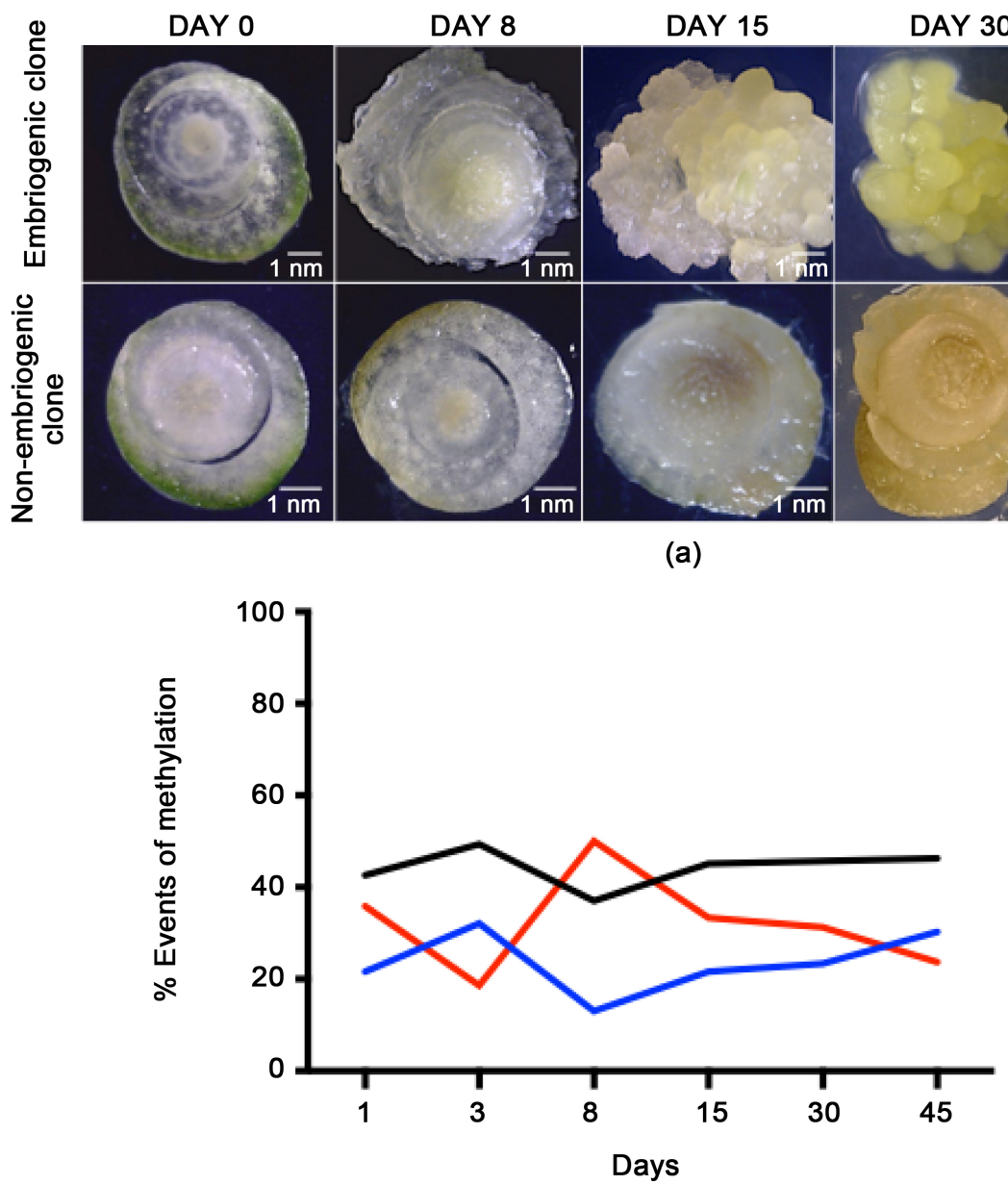

(b)

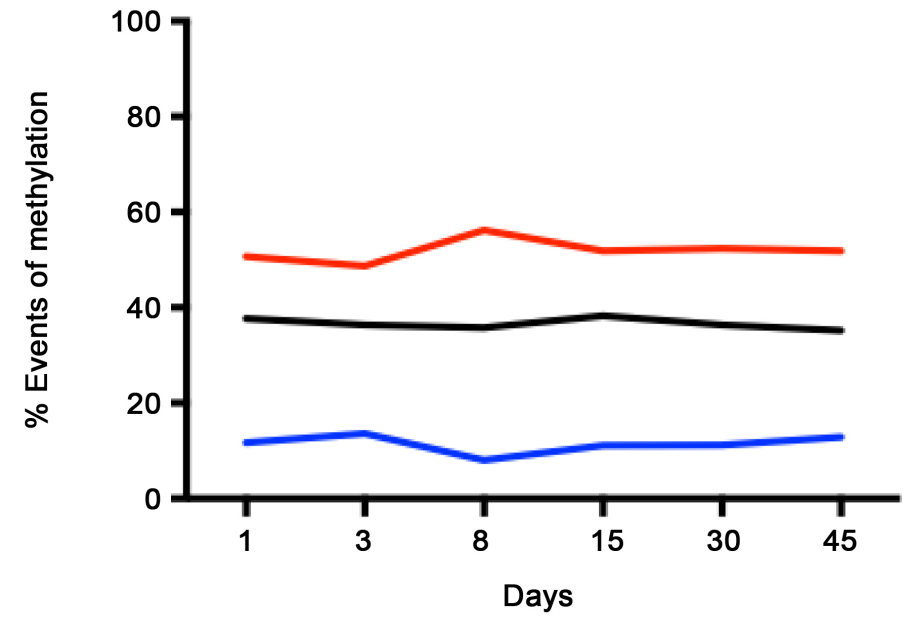

(c)

Figure 3. (a) Responses to induction of somatic embryogenesis of an embryogenic clone (top) and a non-embryogenic clone (bottom) of Agave fourcroydes, (b) Percentage of methylation events in an embryogenic clone (K33); (c) Percentage of methylation events in a non-embryogenic clone (K7).

fourcroydes, a value that is much lower than those found in this work (55.04\% for K33 and $64.73 \%$ for K7). In A. tequilana, using the same molecular marker, 
Diaz et al. (2013) detected no genetic variation (0 polymorphic bands) between the original explant and four generations of in vitro cultured plants. However, Torres-Morán et al. (2010), using ISTR as a marker, observed that genetic variability existed in plants generated by in vitro culture methods (somatic embryogenesis and axillary buds) for $A$. tequilana.

The differences in genetic stability observed in this work and previous reports may be due to various factors, such as the type of species, molecular marker, propagation path, explant, culture medium, growth regulators and time of culturing in in vitro conditions. In this study, before undergoing embryogenic induction, both clonal lines were kept in maintenance medium with 2,4-D and BA for 15 subculture cycles ( 1 month of subculture). It has been reported that the duration, the number of subculture cycles and exposition to plant growth regulators may cause somaclonal variation [46] [51] [52] [53].

Epigenetic variability has been little studied in in vitro-cultured plants of Agave. Díaz-Martínez et al. (2012) studied methylation patterns between the original explant and four generations of in vitro-cultured plants of $A$. tequilana, noting that each generation showed specific patterns. In other species, it has been observed that micropropagated plants present epigenetic variations in relation to the parental plant [16] [45] [54].

In spite of the genetic and epigenetic variability within clonal lines, both were separated into two groups using both techniques (Figure 1). This separation is possibly due to the conservation of some markers (genetic and/or epigenetic) of the parental plant. In a previous study with $A$. fourcroydes, it was observed that each mother plant and its somatic embryogenesis-derived daughter plants clustered, indicating the conservation of superior characteristics in the micropropagated daughter plants [48].

\subsection{DNA Methylation Patterns before SE Induction}

In this study, MSAP revealed that clonal lines K33 and K7, which have high or null embryogenic potential, respectively, showed epigenetic differences (DNA methylation at CCGG sites) before undergoing embryogenic induction. Even when using the same explant (stem shoots), the clonal lines each had fragments with specific methylation states and shared only $54.94 \%$ of fragments with the same methylation pattern (Table 5). It has been reported that different plant genotypes present differences in their DNA methylation patterns [18] [55] [56] and between tissues in an individual [57].

Cells seem to have their own epigenetic signature inserted into the genotype [58]. However, during in vitro culture, some cells are subject to epigenetic reprogramming that results in the elimination of existing epigenetic markers in the nuclei, followed by establishment of a series of different markers [59].

Although the same tissue was used as the explant for SE induction, the responses were very different in the two clonal lines (Figure 3); perhaps the cells involved in embryo formation present an epigenetic status that was different in 
the stem of the embryogenic clonal line compared to that in the stem of the non-embryogenic clonal line. The role of methylation in embryogenic capacity has been reported in Brassica oleracea, in which two types of explants that share the same genome, hypocotyl (more embryogenic) and cotyledon (less embryogenic), show differences in both the DNA methylation levels and the methylation patterns of CCGG sites [6]. In Pinus, the differentiation of needle explants and its relationship with organogenic capability has been associated with increases in heterochromatin-related epigenetic markers, including high DNA methylation, low acetylated histone $\mathrm{H} 4$ levels, and the presence of histone $\mathrm{H} 3$ methylated at Lys9 [60].

\subsection{Dynamics of DNA Methylation Patterns during SE Induction}

The stress generated by in vitro culture conditions, especially the exposure to the high concentration of auxin used for SE induction, can lead to the activation of the embryogenic program [1] [2]. In this study, when exposed to growth regulators (in this case, dicamba), K33 began the embryogenic process; however, these same conditions did not induce embryogenesis in similar explants of $\mathrm{K} 7$, which possibly implies a different capacity of genetic-epigenetic response, as indicated by the fact that before being induced, both clones showed different genetic and epigenetic profiles.

The embryogenic clonal line (K33) showed more dynamic changes in methylation-demethylation events (at CCGG sites) compared to the non-embryogenic clonal line (K7) (Figure 3(a)). This plasticity (methylation/demethylation) is related to the regulation of several genes involved in SE [2] [61] and to embryo development [11] [62].

Demethylation events at CCGG sites were observed on day 3 (swelling of explants) and during the formation of somatic embryos (days 15, 30 and 45). It has been observed that the decrease in DNA methylation is related to the developmental process [7] [63] [64] [65] [66].

In the non-embryogenic clonal line (K7), the methylation events at CCGG sites were more frequent and remained constant throughout the process (Figure 3(b)), which might be the cause of the inhibition of developmental gene expression in the embryogenic process. In Eleutherococcus senticosus, it has been observed that the non-embryogenic callus presented a higher level of methylation compared with the embryogenic callus [9].

Different studies show that epigenetic changes might be related to totipotency acquisition, cellular reprogramming, induction of SE, and embryo development [2] [15] [61]. In this work, we observed that both clonal lines showed different genetic and epigenetic patterns before beginning the induction process (even when using the same explant). Furthermore, when they were subjected to the induction process, the embryogenic line presented greater dynamism in terms of methylation-demethylation events (at CCGG sites), whereas the non-embryogenic line presented high numbers of methylation events throughout the process. 
From these results, we hypothesize that, in addition to genetic differences, methylation polymorphisms between clonal lines (K33 and K7) could be responsible for their different responses to SE induction factors.

\section{References}

[1] Fehér, A. (2008) The Initiation Phase of Somatic Embryogenesis: What We Know and What We Don't. Acta Biologica Szegediensis, 52, 53-56.

[2] Fehér, A. (2015) Somatic Embryogenesis-Stress-Induced Remodeling of Plant Cell Fate. Biochimica et Biophysica Acta (BBA), 1849, 385-402. https://doi.org/10.1016/j.bbagrm.2014.07.005

[3] Rose, R.J., Mantiri, F.R., Kurdyukov, S., Chen, S., Wang, X., Nolan, K.E. and Sheahan, M.B. (2010) Developmental Biology of Somatic Embryogenesis. In: Pua, E.C., Davey, M.R., Eds., Plant Developmental Biology-Biotechnological Perspectives, Springer, Berlin, 3-26. https://doi.org/10.1007/978-3-642-04670-4_1

[4] Law, J.A. and Jacobsen, S.E. (2010) Establishing, Maintaining and Modifying DNA Methylation Patterns in Plants and Animals. Nature Reviews Genetics, 11, 204-220. https://doi.org/10.1038/nrg2719

[5] Palmgren, G., Mattsson, O. and Okkels, F.T. (1991) Specific Levels of DNA Methylation in Various Tissues, Cell Lines, and Cell Types of Daucus carota. Plant Physiology, 95, 174-178. https://doi.org/10.1104/pp.95.1.174

[6] Li, H., Geng, M., Liu, Q., Jin, C., Zhang, Q., Chen, C., Song, W. and Wang, C. (2014) Characteristics of Cytosine Methylation Status and Methyltransferase Genes in the Early Development Stage of Cauliflower (Brassica oleracea L. Var. Botrytis). Plant Cell, Tissue and Organ Culture (PCTOC), 117, 187-199. https://doi.org/10.1007/s11240-014-0432-5

[7] Noceda, C., Salaj, T., Pérez, M., Viejo, M., Cañal, M.J., Salaj, J. and Rodriguez, R. (2009) DNA Demethylation and Decrease on Free Polyamines Is Associated with the Embryogenic Capacity of Pinus Nigra Arn. Cell Culture. Trees, 23, 1285-1293. https://doi.org/10.1007/s00468-009-0370-8

[8] Xu, M., Li, X. and Korban, S.S. (2004) DNA-Methylation Alterations and Exchanges during in Vitro Cellular Differentiation in Rose (Rosa hybrida L.). TAG. Theoretical and Applied Genetics. Theoretische und Angewandte Genetik, 109, 899-910. https://doi.org/10.1007/s00122-004-1717-6

[9] Chakrabarty, D., Yu, K.W. and Paek, K.Y. (2003) Detection of DNA Methylation Changes during Somatic Embryogenesis of Siberian Ginseng (Eleuterococcus senticosus). Plant Science, 165, 61-68. https://doi.org/10.1016/S0168-9452(03)00127-4

[10] Leljak-Levanić, D., Bauer, N., Mihaljević, S. and Jelaska, S. (2004) Changes in DNA Methylation during Somatic Embryogenesis in Cucurbita pepo L. Plant Cell Reports, 23, 120-127. https://doi.org/10.1007/s00299-004-0819-6

[11] Nic-Can, G.I., López-Torres, A., Barredo-Pool, F., Wrobel, K., Loyola-Vargas, V.M., Rojas-Herrera, R. and De-la-Peña, C. (2013) New Insights into Somatic Embryogenesis: LEAFY COTYLEDON1, BABY BOOM1 and WUSCHEL-RELATED HOMEOBOX4 Are Epigenetically Regulated in Coffea canephora. PLoS ONE, 8.

[12] Klimaszewska, K., Noceda, C., Pelletier, G., Label, P., Rodriguez, R. and Lelu-Walter, M.A. (2009) Biological Characterization of Young and Aged Embryogenic Cultures of Pinus Pinaster (Ait.). In Vitro Cellular and Developmental Biology_Plant, 45, 20-33. https://doi.org/10.1007/s11627-008-9158-6

[13] Bobadilla Landey, R., Cenci, A., Guyot, R., Bertrand, B., Georget, F., Dechamp, E., 
Herrera, J.-C., Aribi, J., Lashermes, P. and Etienne, H. (2015) Assessment of Genetic and Epigenetic Changes during Cell Culture Ageing and Relations with Somaclonal Variation in Coffea Arabica. Plant Cell Tissue Organ Culture, 122, 517-531. https://doi.org/10.1007/s11240-015-0772-9

[14] Shibukawa, T., Yazawa, K., Kikuchi, A. and Kamada, H. (2009) Possible Involvement of DNA Methylation on Expression Regulation of Carrot LEC1 Gene in Its 5'-Upstream Region. Gene, 437, 22-31. https://doi.org/10.1016/j.gene.2009.02.011

[15] Wickramasuriya, A.M. and Dunwell, J.M. (2015) Global Scale Transcriptome Analysis of Arabidopsis Embryogenesis in Vitro. BMC Genomics, 16, 301. https://doi.org/10.1186/s12864-015-1504-6

[16] Jaligot, E., Beulé, T., Baurens, F.-C., Billote, N. and Rival, A. (2004) Search for Methylation-Sensitive Amplification Polymorphism Associated with the "Mantled" Variant Phenotype in Oil Palm (Elais gineensis Jacq.). Genome, 47, 224-228.

[17] Cristofolini, C., do Nascimento Vieira, L., de Freitas Fraga, H.P., da Costa, I.R., Guerra, M.P. and Pescador, R. (2014) DNA Methylation Patterns and Karyotype Analysis of Off-Type and Normal Phenotype Somatic Embryos of Feijoa. Theoretical and Experimental Plant Physiology, 26, 217-224. https://doi.org/10.1007/s40626-014-0020-4

[18] Choi, J.-Y., Roy, N.S., Park, K.-C. and Kim, N.-S. (2016) Comparison of Molecular Genetic Utilities of TD, AFLP, and MSAP among the Accessions of Japonica, Indica, and Tongil of Oryza sativa L. Genes \& Genomics, 38, 819-830.

[19] Miyashita, T., Kunitake, H., Yotsukura, N. and Hoshino, Y. (2015) Assessment of Genetic Relationships among Cultivated and Wild Rubus Accessions Using AFLP Markers. Scientia Horticulturae, 193, 165-173.

[20] Gresta, F., Mercati, F., Santonoceto, C., Abenavoli, M.R., Ceravolo, G., Araniti, F., Anastasi, U. and Sunseri, F. (2016) Morpho-Agronomic and AFLP Characterization to Explore Guar (Cyamopsis tetragonoloba L.) Genotypes for the Mediterranean Environment. Industrial Crops and Products, 86, 23-30.

[21] Yang, S., Guo, N. and Ge, H. (2016) Morphological and AFLP-Based Genetic Diversity in Rosa Platyacantha Population in Eastern Tianshan Mountains of Northwestern China. Horticultural Plant Journal, 2, 55-60.

[22] Covelo-Soto, L., Saura, M. and Morán, P. (2015) Does DNA Methylation Regulate Metamorphosis? The Case of the Sea Lamprey (Petromyzon marinus) as an Example. Comparative Biochemistry and Physiology Part B: Biochemistry and Molecular Biology, 185, 42-46. https://doi.org/10.1016/j.cbpb.2015.03.007

[23] Covelo-Soto, L., Leunda, P.M., Pérez-Figueroa, A. and Morán, P. (2015) Genome-Wide Methylation Study of Diploid and Triploid Brown Trout (Salmo trutta L.). Animal Genetics, 46, 280-288. https://doi.org/10.1111/age.12287

[24] González, A., Sáiz, A., Acedo, A., Ruiz, M. and Polanco, C. (2013) Analysis of Genomic DNA Methylation Patterns in Regenerated and Control Plants of Rye (Secale cereale L.). Plant Growth Regulation, 70, 227-236.

https://doi.org/10.1007/s10725-013-9794-7

[25] Osabe, K., Clement, J.D., Bedon, F., Pettolino, F.A., Ziolkowski, L., Llewellyn, D.J., Finnegan, E.J. and Wilson, I.W. (2014) Genetic and DNA Methylation Changes in Cotton (Gossypium) Genotypes and Tissues. PLOS ONE, 9, e86049. https://doi.org/10.1371/journal.pone.0086049

[26] Rathore, M.S., Mastan, S.G. and Agarwal, P.K. (2014) Evaluation of DNA Methylation Using Methylation-Sensitive Amplification Polymorphism in Plant Tissues Grown in Vivo and in Vitro. Plant Growth Regulation, 75, 11-19. 
[27] More, P., Agarwal, P., Mastan, S.G. and Agarwal, P.K. (2016) MSAP Marker Based DNA Methylation Study in Salicornia Brachiata DREB2A Transgenic Tobacco. Plant Gene, 6, 77-81.

[28] Wang, Q.M., Wang, L., Zhou, Y., Cui, J., Wang, Y. and Zhao, C. (2016) Leaf Patterning of Clivia miniata var. variegata Is Associated with Differential DNA Methylation. Plant Cell Reports, 35, 167-184. https://doi.org/10.1007/s00299-015-1877-7

[29] Lira-Medeiros, C.F., Parisod, C., Fernandes, R.A., Mata, C.S., Cardoso, M.A. and Ferreira, P.C.G. (2010) Epigenetic Variation in Mangrove Plants Occurring in Contrasting Natural Environment. PLoS ONE, 5, e10326. https://doi.org/10.1371/journal.pone.0010326

[30] Herrera, C.M. and Bazaga, P. (2010) Epigenetic Differentiation and Relationship to Adaptive Genetic Divergence in Discrete Populations of the Violet Viola Cazorlensis. The New Phytologist, 187, 867-876. https://doi.org/10.1111/j.1469-8137.2010.03298.x

[31] Peng, H., Jiang, G.H., Zhang, J., Zhang, W. and Zhai, W.X. (2013) DNA Methylation Polymorphism and Stability in Chinese Indica Hybrid Rice. Science China Life Sciences, 56, 1097-1106. https://doi.org/10.1007/s11427-013-4576-Z

[32] Robert, M.L., Herrera-Herrera, J.L., Castillo, E., Ojeda, G. and Herrera-Alamillo, M.A. (2006) An Efficient Method for the Micropropagation of Agave Species. In: Loyola-Vargas, V.M. and Vázquez-Flota, F., Eds., Plant Cell Culture Protocols, 2nd Edition, Humana Press Inc., Totowa, 165-178.

[33] Monja-Mio, K.M. and Robert, M.L. (2016) Erratum to: Direct Somatic Embryogenesis of Agave Fourcroydes Lem. through Thin Cell Layer Culture. In Vitro Cellular \& Developmental Biology-Plant, 52, 212. https://doi.org/10.1007/s11627-015-9742-5

[34] Robert, M., Herrera-Herrera, J., Herrera-Alamillo, M., Quijano, A. and Balám, U. (2004) Manual for the in Vitro Culture of Agaves. United Nations Industrial Development Organization. Common Fund for Commodities, Vienna.

[35] Murashige, T. and Skoog, F. (1962) A Revised Medium for Rapid Growth and Bioassays with Tobacco Tissue Cultures. Physiologia Plantarum, 15, 473-497. https://doi.org/10.1111/j.1399-3054.1962.tb08052.x

[36] Phillips, G.C. and Collins, G. (1979) In Vitro Tissue Culture of Select Legumes and Plant Regeneration from Callus Cultures of Red Clover. Crop Science, 19, 59-64. https://doi.org/10.2135/cropsci1979.0011183X001900010014x

[37] Echevarría-Machado, I., Sánchez-Cach, L.A., Hernández-Zepeda, C., Rivera-Madrid, R. and Moreno-Valenzuela, O.A. (2005) A Simple and Efficient Method for Isolation of DNA in High Mucilaginous Plant Tissues. Molecular Biotechnology, 31, 129-135. https://doi.org/10.1385/MB:31:2:129

[38] Vos, P., Hogers, R., Bleeker, M., Reijans, M., van de Lee, T., Hornes, M., Frijters, A., Pot, J., Peleman, J. and Kuiper, M. (1995) AFLP: A New Technique for DNA Fingerprinting. Nucleic Acids Research, 23, 4407-4414.

http://www.ncbi.nlm.nih.gov/pubmed/10206688 https://doi.org/10.1093/nar/23.21.4407

[39] Xu, M., Li, X. and Korban, S.S. (2000) AFLP-Based Detection of DNA Methylation. Plant Molecular Biology Reporter, 18, 361-368. https://doi.org/10.1007/BF02825064

[40] Nei, M. and Li, W. (1979) Mathematical Model for Studying Genetic Variation in Terms of Restriction Endonucleases. Proceedings of the National Academy of Sciences of the United States of America, 76, 5269-5273. 
https://doi.org/10.1073/pnas.76.10.5269

[41] Schulz, B., Eckstein, R.L. and Durka, W. (2013) Scoring and Analysis of Methylation-Sensitive Amplification Polymorphisms for Epigenetic Population Studies. Molecular Ecology Resources, 13, 642-653. https://doi.org/10.1111/1755-0998.12100

[42] Excoffier, L., Smouse, P.E. and Quattro, J.M. (1992) Analysis of Molecular Variance Inferred from Metric Distances among DNA Haplotypes: Application to Human Mitochondrial DNA Restriction Data. Genetics, 131, 479-491.

[43] Vázquez, A.M. (2001) Insight into Somaclonal Variation. Plant Biosystems-An International Journal Dealing with all Aspects of Plant Biology, 135, 57-62. https://doi.org/10.1080/11263500112331350650

[44] Vázquez, A. and Lincacero, R. (2010) Stress and Somaclonal Variation. In: Pua, E.-C. and Davey, M.R., Eds., Plant Devlopmental Biology-Biotechnological Perspective, Springer-V., Berlin Heidelberg, 45-64. https://doi.org/10.1007/978-3-642-04670-4_3

[45] Miguel, C. and Marum, L. (2011) An Epigenetic View of Plant Cells Cultured in Vitro: Somaclonal Variation and Beyond. Journal of Experimental Botany, 62, 3713-3725. https://doi.org/10.1093/jxb/err155

[46] Azma, A., Mhiri, C., Grandbastien, M. and Tam, S. (2013) Transposable Elements and the Detection of Somaclonal Variation in Plant Tissue Culture. Malaysian Applied Biology, 43, 1-24.

[47] Zhang, D., Wang, Z., Wang, N., Gao, Y., Liu, Y., Wu, Y., Bai, Y., Zhang, Z., Lin, X., Dong, Y., Ou, X., Xu, C. and Liu, B. (2014) Tissue Culture-Induced Heritable Genomic Variation in Rice, and Their Phenotypic Implications. PLoS ONE, 9, 5-7. https://doi.org/10.1371/journal.pone.0096879

[48] González, G., Alemán, S. and Infante, D. (2003) Asexual Genetic Variability in Agave Fourcroydes II: Selection among Individuals in a Clonally Propagated Population. Plant Science, 165, 595-601. https://doi.org/10.1016/S0168-9452(03)00227-9

[49] Torres-Morán, M.I., Escoto-Delgadillo, M., Molina-Moret, S., Rivera-Rodríguez, D.M., Velasco-Ramírez, A.P., Infante, D. and Portillo, L. (2010) Assessment of Genetic Fidelity among Agave Tequilana Plants Propagated Asexually via Rhizomes versus in Vitro Culture. Plant Cell, Tissue and Organ Culture, 103, 403-409. https://doi.org/10.1007/s11240-010-9777-6

[50] Díaz-Martínez, M., Nava-Cedillo, A., Guzmán-López, J.A., Escobar-Guzmán, R. and Simpson, J. (2012) Polymorphism and Methylation Patterns in Agave tequilana Weber Var. "Azul” Plants Propagated Asexually by Three Different Methods. Plant Science: An International Journal of Experimental Plant Biology, 185-186, 321-330.

[51] Khan, S., Saeed, B. and Kauser, N. (2011) Establishment of Genetic Fidelity of in-Vitro Raised Banana Plantlets. Pakistan Journal of Botany, 43, 233-242.

[52] Leva, A.R., Petruccelli, R. and Rinaldi, L.M.R. (2012) Somaclonal Variation in Tissue Culture: A Case Study with Olive. In: Leva, A. and Rinaldi, L.M.R., Eds., Recent Advances in Plant in Vitro Culture, InTech, London, 123-150. https://doi.org/10.5772/50367

[53] Krishna, H., Alizadeh, M., Singh, D., Singh, U., Chauhan, N., Eftekhari, M. and Sadh, R.K. (2016) Somaclonal Variations and Their Applications in Horticultural Crops Improvement. 3 Biotech, 6, 54. https://doi.org/10.1007/s13205-016-0389-7

[54] Peraza-Echeverria, S., Herrera-Valencia, V.A. and Kay, A.-J. (2001) Detection of DNA Methylation Changes in Micropropagated Banana Plants Using Methylation-Sensitive Amplification Polymorphism (MSAP). Plant Science, 161, 359-367. 
https://doi.org/10.1016/S0168-9452(01)00421-6

[55] Eichten, S.R., Briskine, R., Song, J., Li, Q., Swanson-Wagner, R., Hermanson, P.J., Waters, A.J., Starr, E., West, P.T., Tiffin, P., Myers, C.L., Vaughn, M.W. and Springer, N.M. (2013) Epigenetic and Genetic Influences on DNA Methylation Variation in Maize Populations. The Plant Cell, 25, 2783-2797.

https://doi.org/10.1105/tpc.113.114793

[56] Sáez-Laguna, E., Guevara, M.A., Díaz, L.M., Sánchez-Gómez, D., Collada, C., Aranda, I. and Cervera, M.T. (2014) Epigenetic Variability in the Genetically Uniform Forest Tree Species Pinus pinea L. PLoS ONE, 9, e103145. https://doi.org/10.1371/journal.pone.0103145

[57] Lu, Y., Rong, T. and Cao, M. (2008) Analysis of DNA Methylation in Different Maize Tissues. Journal of Genetics and Genomics, 35, 41-48. https://doi.org/10.1016/S1673-8527(08)60006-5

[58] Morgan, H.D., Santos, F., Green, K., Dean, W. and Reik, W. (2005) Epigenetic Reprogramming in Mammals. Human Molecular Genetics, 14, R47-R58. https://doi.org/10.1093/hmg/ddi114

[59] Viejo, M., Santamaría, M.E., Rodríguez, J.L., Valledor, L., Meijón, M., Pérez, M., Pascual, J., Hasbún, R., Fraga, M.F., Berdasco, M., Toorop, P.E., Cañal, M.J. and Fernández, R.R. (2012) Epigenetics, the Role of DNA Methylation in Tree Decelopment. In: Loyola-Vargas, V.M. and Ochoa-Alejo, N., Eds., Plant Cell Culture Protocols, Methods in Molecular Biology, Humana Press, Totowa, 277-301. https://doi.org/10.1007/978-1-61779-818-4_22

[60] Valledor, L., Meijón, M., Hasbún, R., Jesús Cañal, M. and Rodríguez, R. (2010) Variations in DNA Methylation, Acetylated Histone H4, and Methylated Histone H3 during Pinus Radiata Needle Maturation in Relation to the Loss of in Vitro Organogenic Capability. Journal of Plant Physiology, 167, 351-357. https://doi.org/10.1016/j.jplph.2009.09.018

[61] De-la-peña, C., Nic-can, G.I., Galaz-ávalos, R.M., Avilez-Montalvo, R. and Loyola-vargas, V.M. (2015) The Role of Chromatin Modifications in Somatic Embryogenesis in Plants. Frontiers in Plant Science, 6, 1-15.

[62] Teyssier, C., Maury, S., Beaufour, M., Grondin, C., Delaunay, A., Le Metté, C., Ader, K., Cadene, M., Label, P. and Lelu-Walter, M.A. (2014) In Search of Markers for Somatic Embryo Maturation in Hybrid Larch (Larix $\times$ Eurolepis): Global DNA Methylation and Proteomic Analyses. Physiologia Plantarum, 150, 271-291. https://doi.org/10.1111/ppl.12081

[63] Li, Z., Li, J., Liu, Y. and Wang, Z. (2016) DNA Demethylation during Chrysanthemum Floral Transition Following Short-Day Treatment. Electronic Journal of Biotechnology, 21, 77-81.

[64] Portis, E., Acquadro, A., Comino, C. and Lanteri, S. (2004) Analysis of DNA Methylation during Germination of Pepper (Capsicum annuum L.) Seeds Using Methylation-Sensitive Amplification Polymorphism (MSAP). Plant Science, 166, 169-178. https://doi.org/10.1016/j.plantsci.2003.09.004

[65] Viejo, M., Rodríguez, R., Valledor, L., Pérez, M., Cañal, M.J. and Hasbún, R. (2010) DNA Methylation during Sexual Embryogenesis and Implications on the Induction of Somatic Embryogenesis in Castanea Sativa Miller. Sexual Plant Reproduction, 23, 315-323. https://doi.org/10.1007/s00497-010-0145-9

[66] Rodriguez-Sanz, H., Manzanera, J.-A., Solis, M.-T., Gómez-Garay, A. and Pintos, B. (2014) Early Markers Are Present in Both Embryogenesis Pathways from Microspores and Immature Zygotic Embryos in Cork Oak, Quercus suber L. BMC Plant Biology, 14, 224-242. https://doi.org/10.1186/s12870-014-0224-4 